\title{
Physidae (Mollusca: Gastropoda) of western and central European range - morphological diversification and ecological features
}

\section{Anna Cieplok ( $\square$ anna.cieplok@us.edu.pl )}

University of Silesia https://orcid.org/0000-0001-8350-4746

\section{Roy Anderson}

Belvoirview Park Newtownbreda, Belfast, Ireland UK

\section{Magdalena Gawlak}

Institute of Plant Protection National Research Institute: Instytut Ochrony Roslin

\section{Tomasz Kałuski}

Institute of Plant Protection National Research Institute: Instytut Ochrony Roslin

\section{Aneta Spyra}

University of Silesia: Uniwersytet Slaski w Katowicach

\section{Research}

Keywords: Freshwater snails, alien species, systematics, SEM, morphology, identification key

Posted Date: April 7th, 2021

DOl: https://doi.org/10.21203/rs.3.rs-390369/v1

License: (9) This work is licensed under a Creative Commons Attribution 4.0 International License. Read Full License 


\section{Abstract}

Background: This is the first comparative study on Physidae identified in west and central Europe range. A thorough exploration of morphology supported by ecological features and distribution of European Physidae species are presented within this study. In the context of the lack of research on detailed morphology features on Physidae species we deeply analysed taxonomical features of snails which are being identified more and more frequently in the last years in the territory of the west and central Europe. Scanning electron microscopy (SEM) methods were used to elucidate the external morphology of freshwater snails (Mollusca: Gastropoda: Physidae), that occur in the area of western and central part of Europe. We compared the external morphology of their shells and found important differences between the species.

Results: Morphological analysis are benefited in revealing variations of Physide shells. We found intraspecific similarities within Physidae, which are the most evident in the overall structure of shells and the height of the spires. Many interspecific differences in morphology in the apex structure and spires were found. From our results, we can infer that the shells $P$. fontinalis and $A$. hypnorum had the lowest amount of variability between particular individuals. The most characteristic features and differences of representatives of Physidae are presented and discussed. This is especially important in Physa gyrina and a worldwide invader Physa acuta identification which is shape-wise not easy to distinguish.

Conclusions: The implications of our study are new identification key along with the ecological characteristic of physid species and the assessment of their current range in Europe. Our data demonstrate similarities within Physidae, which are the most evident in the overall structure of shells, and the height of the spires, apex structure, and spires were found between analysed species and provide further evidence of the importance of morphological features as an identification driver.

\section{Background}

Physidae is a world-wide family of freshwater snails, which comprises about 80 species $^{[1]}$ that have a Holarctic and Neotropical distribution ${ }^{[2]}$. Physidae are found on almost all continents and many remote islands ${ }^{[1,3-7]}$. Much of this range is due to their recent artificial introduction ${ }^{[1,8]}$. Physidae are known as common freshwater snails that occur in readily accessible habitats such as ditches, ponds, lakes, small streams, and rivers ${ }^{[9-11]}$.

The Physidae family are the most frequently divided into six group: aplexa, marmorata, fontinalis, acuta, gyrina and pomili, which are phylogenetically varied and have distinctive penial and shell morphology ${ }^{[12]}$. Genetic variations and the absence of reproductive isolation between the nominal species are the reasons why many species are lumped together under the name of Physa acuta including $P$. heterostropha, $P$. integra, $P$. virgata and $P$. cubensis ${ }^{[11]}$. Physella heterostropha was reduced to a synonymy with $P$. acuta on the basis of both morphological homogeneity ${ }^{[13]}$ and a lack of breeding isolation in experiments conducted on N. American samples ${ }^{[11]}$. 
In western and central part of Europe, the following species from the Physidae family have been observed: Physella gyrina, Physa fontinalis, Aplexa hypnorum and Physella acuta - alien a species that are also called as globally invasive ${ }^{[14,15]}$. In the studied area, Physa adversa was also described, however, only at two sites ${ }^{[16]}$ where it is considered to be extremely rare and is sometimes regarded as a synonym to Physa fontinalis ${ }^{[17]}$. Physa gyrina is a North American species that was introduced into Europe and was recorded in England, Ireland, the Spanish mainland, and Austria, but its distribution has described as being worldwide ${ }^{[1,8]}$. It occurs in lakes, streams, ponds, ditches and marshes. Physa fontinalis is a good indicator of unpolluted conditions ${ }^{[10]}$, is associated with plants and mainly inhabits small water bodies, streams or canals ${ }^{[18]}$. Aplexa hypnorum, which usually occurs in small numbers of specimens, is a species typical to swampy pools, ditches, lakes and forest ponds ${ }^{[10,16,19]}$, and has little variation in the shape of its shell ${ }^{[9]}$. Physa acuta occurs in many areas and is widely regarded as an immigrant from North America ${ }^{[2]}$. This species was introduced into Europe, Africa, Asia and Australia via human commerce and migrating birds ${ }^{[7,20]}$.

The shell of Physidae specimens is sinistral, ovate or ovate conical, thin, has no umbliculus, up to $11 \mathrm{~mm}$ long, has a depressed spire and dull surface in most of the species. The animal is light grey in colour, with long tentacles. The aperture is differently developed and ranges from large to relatively broad and narrows to a point ${ }^{[18,21]}$. Because of the lack of comprehensive data on the differences in the morphological structure of the shells of the snails from the Physidae family ${ }^{[1]}$, as well as the globally invasive Physella acuta, the aims of the research were to identify the morphological characteristics of the shells of the European species of Physidae, to estimate the inter-and intraspecific features in the morphology of their shells. While Aplexa hypnorum is quite easy distinguishable from other Physidae, Physa gyrina and a worldwide invader Physa acuta are shape-wise not easy to distinguish therefore study aimed to compare and describe any differences in the shells of these species and to compare their biological and ecological features, among others, the ecological characteristics of the sites that they inhabit and the current range of each species. Researchers have been using simple morphological measures as indicators of features that are characteristic of particular species. In this study, we deeply analysed taxonomical features of snails which are being identified more and more frequently in the last years in the territory of the west and central Europe. Adult snail in some cases can be easily identified by morphology, although the smaller specimens are more difficult to identify to the species rank. Because physid species are sometimes morphologically hard to distinguish especially $P$. acuta and $P$. gyrina, sometimes also $P$. fontinalis in the case of smaller specimens this study presents analysis of specimens along with the most characteristic morphological features. We also discuss the morphological features of Physidae with respect to their possible taxonomic and functional significance. Our study is the first comparative study on Physidae identified in west and central Europe range.

\section{Results And Discussion}

\section{Identification of Physidae}


1) Right- handed shells of various shapes- ovate, ovate- conical, spherical or quasi-spherical,

outline elongate, asymmetrical, apex pointed - (Lymnaeidae)

1a) Left-handed shells, spindle-shaped or ovoid-shaped, smooth and thin, have a pointed spire, small - to medium - sized, 5-17 mm. Shells are rather transparent, thin and corneous with relatively large and long aperture without an operculum - Physidae (Fig. 1)

\section{Physidae Genus Key}

1. Shell is narrow and long. Shell smooth and usually very glossy. Body shines through the shell. Snail is found mostly in ephemeral (astatic) water bodies - Genus Aplexa (Fig. 1).

2. Spire of the shell is relatively blunt and short. Rather smooth surface of the shell or with very delicate spiral lines. Snails commonly occur in ponds, rivers and streams - Genus Physa/Physella (Fig. 1, Additional file 1 -S1).

\section{Physidae Species Key}

1a) Shell is tall, slender, narrow, usually very glossy, semi-transparent (Fig. 1 b), with a high spire (Fig. 1, 2 b) and the height of the aperture is about half of the overall height (Fig. 3 a). Aperture narrow, its external part sharp with a lip visible in SEM images (Fig. 3 a and c). Sinistral, spindle-shape. Body whorl not especially large and narrowed at bottom. Body of snail usually black and does not overlap outside of shell. Umbiculus completely covered (Fig. 3 a). Up to $13 \mathrm{~mm} \times 6 \mathrm{~mm}$, usually 8-15 $\times$ 3-6 mm with up to 7 whorls (usually 5.5-6), regularly increasing. Species occur in almost whole Europe, often found in ponds, ditches, forest water bodies and other types of lentic habitats that are temporary, dried out or are characterised by a high fluctuation in the water level (Additional file 1-S1, Fig. 4) - Moss Bladder Snail Aplexa hypnorum (Fig. 1; Fig. 2 a, b and c)

1b) Shell shorter and more rounded, the height of the aperture is at least two thirds of the overall height of the shell. Body of snail pale brown or greenish, Shell up to $18 \mathrm{~mm} \times 11 \mathrm{~mm}$, with up to 4 whorls -2

2a) Shell usually fragile or very delicate, thin, glossy and translucent, also wider. Shell shape is oval in outline (Fig. 1 c, Fig. 5). Short or very short spire, the apex of shell rounded (Fig. 2 c). Spire blunted. 3-4 whorls (Fig. 1 and 5). Aperture high and tapered in upper side. Umbiculus covered. Body whorl inflated (Fig. 5). Sutural belts of shell are very delicate and visible on SEM images (Fig. $5 \mathrm{~b}$ and c). Never more than $12 \mathrm{~mm} \times 8 \mathrm{~mm}$, usually less than $10 \mathrm{~mm}$, with 4 whorls. Occur in the whole western and central Europe in lentic habitats, slow-flowing waters, among detritus in a wide range of pH (Additional file 1- S1, Fig. 4) - Common Bladder Snail - Physa fontinalis .

2b) Shell thicker, rather strong, larger, spire pointed and higher, shell surface smooth - $\mathbf{3}$ 
3a) Shell often thicker, stronger and more opaque, ovate and relatively wide (Fig. 1 a). Spire pointed (1/3 shell height) (Fig. 1, 2 a). Body whorl distinctly inflated. Aperture large, tapered in upper part. Internal white lip at the aperture margin with characteristic thickening visible under SEM (Fig. 6 b and c). Umbiculus covered and sometimes a narrow fissure is visible. Shell corneous, with delicate shining. Often larger than other Physidae, up to $18 \mathrm{~mm} \times 11 \mathrm{~mm}$ (usually $8-16 \times 5-10 \mathrm{~mm}$ ) and up to 6 whorls (usually 5-6). The range of its occurrence is the most part of Europe (Fig.4). Usually found in natural water bodies or those with higher water temperature, occurs in lakes ponds, anthropogenic water bodies, river, stream and ditches, can tolerate a high level of pollution and can be present in degraded water environments (sewage, toxic waters, in high values of $\mathrm{pH}$ values e.g., 9.4) (Additional file - S1) - American

\section{Bladder Snail - Physella acuta}

3b) Snail size to more than $20 \mathrm{~mm}$. Shell is relatively strong, deep horn-coloured and with shallow sutures (Fig. 7 a), apex is broader and blunter than P. acuta (Fig. 2 d). The body pigmentation shows clusters of large white pigment spots, upper whorls with reddish hue, number of whorls is 3-5 which are rather convex, with last whorl predominating (Fig. 1 d), aperture $55-75 \%$ of shell height, with broad white callus on parietal side (Fig. 1 and Fig. 7 b-g, I). Shell shape as well as the size of aperture varied. Characteristic thickened appendages occurred that are visible in SEM images (Fig. $7 \mathrm{e}, \mathrm{f}$ and $\mathrm{h}$ ). Species occur in standing and slowly flowing waters. Species inhabit permanent and temporary ponds, shallow inshore areas and marshes. The current range of its occurrence is shown on Fig. 4. They occur on aquatic plants and organic matter, under stones on shallow gravelly foreshores and tolerate organic water pollution and eutrophic or hypertrophic conditions (Additional file 2-S1) - Physella gyrina

\section{The morphology and habitat characterisation of Physidae}

There is a lack of detailed morphological studies on the Physidae snails that occur in the western and central European range. Penial sheath morphologies and radular characters can sometimes be of limited systematic value within the Physidae family. In practice, most scientist must rely on the general shell features to identify for Physidae. This is why morphological studies on this group of snails are of great importance. Molecular studies and reproductive isolation experiments indicate the need to synonymise some of the physid snails: P. heterostropha (North America), P. virgata (North America), P. integra (North America) and $P$. cubensis (Central and South America) to a single species, Physa acuta ${ }^{[12,22]}$. $P$. acuta is being described as a species with a high plasticity of shell morphology ${ }^{[23]}$. In the review of Anderson [13], British and Irish $P$. acuta and $P$. heterostropha were considered to be the same with $P$. acuta as the correct name, while $P$. gyrina was regarded as a distinct species.

Physidae have some features that allows to be separated from other pulmonate families: a high, spired sinistral shell; radula with teeth in v-shaped rows, and no hemoglobin or pseudobranchia ${ }^{[12,24]}$. We also confirmed that the morphological features of shell are the important for their identification and we also found deep intraspecific similarities within specific species of Physidae. 
After comparing specific features of the shell of the snails from the Physidae family, we can conclude that there are some very important morphological differences in the physid shell structure (Fig. 1). This is most evident in the overall structure of the shells and the height of the spires from the aperture to apex. There are also many differences in Physidae morphology we found in the apex structure and spires. Small specimens of specific species have an apex that is similar to their adult forms (Fig. 2), which is especially important and useful in identifying Physidae when there is more than one physid species in one environment or sample.

While Aplexa hypnorum has a higher spire than the other Physidae, $P$. acuta has a more pointed apex (Fig.3). We found no information on the lip or whether this species has no lip in the identification keys to freshwater snails for Aplexa hypnorum. Our study showed that the Aplexa hypnorum specimens have a lip (Fig. 3, Supplementary figure S2) which however is not always visible under a stereoscopic microscope due to its delicate structure (Fig. 3 a and C).

The $P$. fontinalis apex is rather flat and its spire has a delicate stripes (Fig. 5). Similar to Økland ${ }^{[9]}$, our study showed some variation in the $P$. fontinalis shell. $P$. acuta has a thicker, often less translucent shell (Fig. 1, Fig. 6 a and b, Additional file 1-S1), with a thicker structure of lip (Fig. 6 c). We found that the contact points between the whorls are clearly visible, which is similar to P. gyrina (Fig. 2). When seen under the stereoscopic microscope, Physa acuta lip, has quite clearly visible structures (Fig. $6 \mathrm{~d}$ ), while the lip of $P$. gyrina that is visible under such a microscope is smooth. From our results, we can infer that the shells of the two species of Physidae $P$. fontinalis and A. hypnorum had the least variability between individuals.

Physa gyrina is the common species of snails that has a short spire and rapidly expanding whorls, resulting in a very large aperture on the left side (Fig. 1). In this study, we revealed that the $P$. gyrina shell also has a clearly visible structural belt between the spire (whorls) (Fig. 2). P. gyrina also has plasticity in its shell morphology. Some of the shells of $P$. gyrina also have characteristic thickened appendages that are visible in the SEM images (Fig. $7 \mathrm{e}, \mathrm{f}$ and $\mathrm{h}$ ). Because the characteristic thickened appendages occurred in the lip area of its shell were only present in $10 \%$ of the studied shells, we cannot consider the presence of these structures as a good diagnostic character. However, their presence enabled us to distinguish the individuals from $P$. acuta in which these structures are not present. According to Bolton and Beaudoin ${ }^{[25]}$, the most striking feature of this snail, aside from its coiling direction, is its large aperture and body whorl, which comprise as much as $80 \%$ of the shell height. The specimens collected in this study have an aperture that is less than $80 \%$ of the shell height (Fig. 1). We also found a high number of Cocconeis placentula (Ehrenberg) (Baccillariophyceae) attached to the upper part of the P. gyrina shells (Supplementary Fig. 3 a, b, and c). This species of diatoms is a common component of periphyton, and can be scraped off the surface of snail shells by benthic organisms, which feed on epiphytic organisms ${ }^{[26,27]}$. C. placentula can also be found in the digestive tube of the freshwater snails that feed on periphyton ${ }^{[28]}$. It also thrives abundantly on the surface of both the shells and the aquatic plants. 
The Correspondence Analysis grouped Physidae species according to identified features of their shell morphology (Fig. 8). From the ordination diagram visible is the distinctiveness of $A$. hypnorum due to the shell width and height ratio, the spire, and overall shell height. Physa gyrina and $P$. acuta are the most similar to each other in the terms of shell thickness, height of the spire, the presence of lip and structure of apex. These features in detail were presented on figures and described in the identification key, which we constructed upon the results of our studies. In some cases, especially in the case of smaller (younger) specimens of $P$. fontinalis this species can be difficult to identify, because the shell width, convexity of whorls, and the height of aperture can be similar to P. gyrina and $P$. acuta (Fig. 8).

Molluscs exhibit a wide range of shell shapes as adaptations to the surrounding environmental conditions in which they occur ${ }^{[29]}$. The differences in the shapes of the shell are plastic responses to environmental variation ${ }^{[23,30]}$. Species which were studies differ in the range of occurrence (Fig. 4). $P$. gyrina is being found only in west part of Europe whereas other Physidae species occur in west and central Europe, however they are reported from different countries. Most of the data from the literature indicate that physid snails are quite common in easily accessible habitats such as ditches, ponds, lakes, small streams and rivers (Additional file - S1). Physa gyrina inhabits different temporary or permanent ponds, lakes and lotic ecosystems. This species can occur in harsh environmental conditions as long as the overall environment is stable and rich ${ }^{[12]}$.

Physa acuta is native to North America and is an alien invader in Europe that has been frequently introduced together with the ornamental aquatic plants ${ }^{[1,15,31,32]}$. Both $P$. gyrina and $P$. acuta can occur in waters with different degrees of pollution. Turner and Montgomery ${ }^{[33]}$ found them in permanent habitats in ponds with an intermediate depth and high predator abundance and described $P$. gyrina as a moderately generalised species and $P$. acuta as a remarkably generalised species. In India the occurrence of $P$. acuta is still restricted to the sewage drain habitats ${ }^{[34]}$. In habitats that have a higher water temperature, $P$. acuta benefits compared to other Physids such as, e.g. $P$. fontinalis, which according to the results of the study of Früh et al. ${ }^{[35]}$ is the evidence that the environmental context influences species interactions and impacts of alien species. Our previous study showed that this species can occur in waters with high $\mathrm{pH}$ values ${ }^{[36]}$. According to the study of Paraense and Pointier ${ }^{[5]}, P$. acuta can be described as a ubiquitous species. The physid specimens in this study were collected from different substrates in various types of freshwater environments.

Aplexa hypnorum, which lives on light to moderately clayey bottoms, occurs in small water bodies and ditches that dry out during the summer period as well as in swampy and forested margins of lakes $[16,19,37-39]$. The number of species that are able to survive such circumstances is relatively small, which is probably the reason why this species is found at low densities. Earlier studies in forest ponds showed that $A$. hypnorum can tolerate acidic waters $(\mathrm{pH}<6)^{[36]}$. In some countries, it is placed on the lists of species that have been evaluated as being regionally extinct or that are under threat of regional extinction, e.g. in Ireland ${ }^{[39]}$. 
This study demonstrates that the morphological structure of the shells can be used to reliably identify Physid species. Therefore, it seems that a correctly classified morphological features of shells along with the knowledge of the ecology of the studied species, can be the best approach to proper identification these species within their European range. This is of special importance in the case of Physa gyrina and a worldwide invader Physa acuta identification which is shape-wise not easy to distinguish and because $P$. acuta constantly increases the area outside the natural range and it is more and more widely spread.

\section{Conclusions}

We present deeply analysed taxonomical features of snails which are being identified more and more frequently in the last years in the territory of the west and central Europe using Scanning electron microscopy (SEM). Because Physid species are morphologically hard to distinguish especially $P$. acuta and $P$. gyrina, and also $P$. fontinalis in the case of smaller specimens this study presents an analysis of specimens along with the most characteristic morphological features. In the context of the lack of research on detailed morphology features on Physidae species, the implications of our study are constructed based on our analysis identification key, along with the ecological characteristic of physid species and the assessment of their current range in Europe. Our data demonstrate intraspecific similarities within Physidae, which are the most evident in the overall structure of shells, and the height of the spires, apex structure, and spires. Comparative features found and analysed between analysed species provide further evidence of the importance of morphological features as an identification driver. This is especially important in Physa gyrina and a worldwide invader Physa acuta identification which is shape-wise not easy to distinguish. From our results, we can also infer that the shells $P$. fontinalis and $A$. hypnorum had the lowest amount of variability between particular individuals. Correctly classified morphological features of shells along with the knowledge of the ecology of the studied species can be a proper approach to correctly identify these species within their European range and can be used to reliably identify Physidae species.

\section{Methods}

\section{Sampling and laboratory analysing the Physidae}

At the beginning of this study, we selected the Physid species that occur on the entire territory of Europe. However, some of them occur as only a single specimen at some sampling sites and therefore they were not available to us. This was the reason why four species of freshwater snails from the Physidae family in western and central European range were considered in this study.

P. gyrina was collected from Wales, Ireland and Poland. In Wales the specimens were sampled in Gwent Levels in pond in flood plain (I. Killen). In Ireland snails were collected in Lough Neagh sheltered sandy bay, in Castleroe on the River Bann which drains Lough Neagh as well as the Argory, co Armag where they were sampled in the ditch. In Poland Physidae species were sampled from different types of water bodies and river (Central and Southern Poland). Snails were taken in the field using the qualitative 
hydrobiological methods of sampling ${ }^{[18]}$. After they were collected, the snails were transported to the laboratory, they were sorted using stereoscopic microscope, preserved in $80 \%$ ethanol and identified. Some of the specimens after separating their bodies from the shells, were dried it at $40^{\circ} \mathrm{C}$ in a laboratory dryer, they were kept dry for further analysis.

Both Stereoscopic Microscopy (SM) and Scanning Electron Microscopy (SEM) were used to elucidate the external morphology of the European species of the Physidae family. We analysed and compared their external morphology. For each taxon, a brief highlight of its most striking morphological characteristics and its general ecological niche, as well as more thorough descriptions of each taxon, which are intended for positive identification, are presented in the key and in the photographs. For each of the Physidae species, a brief summary of their characteristics and information on their ecological preferences, life cycles and occurrence were also compiled (supplementary information). The current range of each species of Physidae were analysed, compared and presented on map. Both SEM micrograph and photographs from stereoscopic microscope (SM) were finally prepared with Corel DRAW 2017 Graphic (64-Bit).

\section{Scanning electron microscopy}

Observations of shells were carried out using scanning electron microscope (SEM) S-3000N Hitachi. The research was conducted at the Institute of Plant Protection - National Research Institute in Poznan. Dry shells were attached to a stub using double-sided adhesive carbon discs. The samples were coated with gold/palladium and photographed with an SEM using a secondary electron detector (SE).

\section{Stereoscopic microscopy}

The following photographs of the Physidae specimens from the territory of Western and Central Europe were taken as a part of the morphological studies on their shells. The hells were examined with an OLYMPUS SZX16 stereoscopic microscope (SM) and photographed using an OLYMPUS DP72 camera and Cell Sens Standard 1.4 (Build 8583, Olympus Camera Software Ver. for Microsoft Windows NT 6.1).

The analysis were carried out in the Institute of Biology, Biotechnology and Environmental Protection, Faculty of Natural Sciences, University of Silesia in Katowice (Poland).

\section{Statistical analysis}

In the statistical analysis the Correspondence Analysis (CA) was used to determine which variables defining the morphological features of Physidae snails, which characterise each species the most. CA is based on different kinds of categorical data (datasets grouped into categories). With more data, CA can uncover more subtle distinctions among groups within a particular category. The CA analysis was preceded by using a Detrended Correspondence Analysis (DCA) in order to check the nature of the data on the basis of the length of the gradient, which is expressed in standard deviation units. The analyses 
were performed using CANOCO for Windows 4.5. Ordination diagram was created using CanoDraw for Windows ${ }^{(62)}$.

\section{Declarations}

\section{Ethics approval and consent to participate}

The animal analytical procedures were approved by University of Silesia and complied with the current Polish law.

\section{Consent for publication}

Not applicable.

\section{Availability of data and materials}

All data generated or analysed during this study are included in this published article (and its Supplementary Information file). Correspondence and requests for materials should be addressed to A.C.

The dataset supporting the conclusions of this article is included within the article (and its additional file) (Additional file 1)

\section{Competing interests}

The authors declare that they have no competing interests.

\section{Founding}

This research was founded by the University of Silesia, Katowice, Poland. This research did not receive any specific grant from funding agencies in the public, commercial, or not-for-profit sectors.

\section{Author Contributions}

A.C., A.S. conceived the study, A.C. collected material in Poland, performed identification, analysed and reviewed data, interpret the data; prepared photos using Stereoscopic Microscope, A.S., A.C. wrote the manuscript; A.S. prepared final version of the figures. R.A.- sampled material, analysed collection, describe the studied area in Ireland and Wales; M.G. and T.K. performed SEM analysis and SEM micrographs of material; wrote the manuscript,.

\section{Acknowledgements}

We would like to thank Ms. Michele L. Simmons, BA from the English Language Centre (ELC) for all corrections that greatly improved the English language of manuscript. This research did not receive any specific funding. All material has been collected under appropriate approved ethics guidelines. 


\section{References}

1. Taylor, D. W. Introduction to Physidae (Gastropoda: Hygrophila). Biology, classification, morphology. Rev. Biol. Trop. 51, 1-299 (2003).

2. Appleton, C. C., Brackenbury, T. D. \& Tonin, A. F. G. Physa mosambiquensis (Clessin, 1886) rediscovered? Afr. Zool. 24, 340-344 (1989).

3. Burch, J. B. North American freshwater snails. Malacological Publication, 365 pp. (Hamburg, Michigan, 1989).

4. Appleton, C. C. Alien and invasive fresh water Gastropoda in South Africa. Afr. J. Aquat. Sci. 28, 6981 (2003).

5. Paraense, W. L. \& Pointier, J. P. Physa acuta Draparnaud, 1805 (Gastropoda: Physidae): a study of topotypic specimens. Mem. Inst. Oswaldo. Cruz. 98, 513-517 (2003).

6. Balashov, I. A., Son, M. O., Coada, V. \& Welter-Schultes, F. An updated annotated checklist of the molluscs of the Republic of Moldova. Folia Malacol. 21, 175-181 (2013).

7. Ng, T. H., Limpanont, Y., Chusongsang, Y., Chusongsang, P. \& Panha, S. Correcting misidentifications and first confirmation of the globally-invasive Physa acuta Draparnaud, 1805 (Gastropoda:

Physidae) in Thailand and Laos. Biolnvasions Rec. 7, 15-19 (2018).

8. Anderson, R. Physa gyrina (Say), a North American freshwater gastropod new to Ireland, with a key to the British Isles Physidae. The Irish Natu. J., 25, 248-253 (1996).

9. Økland, J. Lakes and snails. Universal Book Services, pp. 516. (Oegstgeest, 1990).

10. Kerney, M. P. Atlas of land and freshwater molluscs of Britain and Ireland. Brill. (1999).

11. Dillon R. T., Wethington, A. R., Rhett, J. M. \& Smith, T. P. Populations of the European freshwater pulmonate Physa acuta are not reproductively isolated from American Physa heterostropha or Physa integra. Invertebr. Biol. 12, 226-234 (2002).

12. Wethington, A. R. \& Guralnik R. Are populations of physids from different hot-springs distinctive lineages? Am. Malacol. Bul. 19, 132-144 (2004).

13. Anderson, R. Physella (Costatella) acuta (Draparnaud) in Britain and Ireland, its taxonomy, origins and relationship to other introduced Physidae. J. Conchol. 38, 7-21 (2003).

14. Lydeard, C., Campbell, D. \& Golz, M. Physa acuta Draparnaud, 1805 should be treated as a native of North America, not Europe. Malacologia 59, 347-350; https://doi.org/10.4002/040.059.0213 (2016).

15. Vinarski, M. V. The history of an invasion: phases of the explosive spread of the physid snail Physella acuta through Europe, Transcaucasia and Central Asia. Biol. Invasions 19, 1273-1288, https://doi.org/10.1007/s10530-016-1339-3. (2017)

16. Glöer, P. \& Diercking, R. Atlas der Süßwassermollusken Hamburg. Rote Liste, Verbreitung, Ökologie. Umweltbehörde, 182 p. (Hamburg, 2010).

17. Vinarski, M. V., Grebennikov, M. E. \& Shishkoedova, O. S. Past and present distribution of Myxas glutinosa (OF Müller, 1774) in the waterbodies of the Urals and Siberia. J. Limnol. 72, 336-342 
(2013).

18. Piechocki, A. \& Wawrzyniak-Wydrowska, B. Guide to freshwater and marine Mollusca of Poland. Bogucki Wydawnictwo Naukowe (Poznań, 2016).

19. Spyra, A. Environmental factors influencing the occurrence of freshwater snails in woodland water bodies. Biologia. 65, 697-703; DOI: 10.2478/s11756-010-0063-1 (2010).

20. Raković, M. J. et al. Haplotype variation in the Physa acuta group (Basommatophora): genetic diversity and distribution in Serbia. Mediterr. Mar. Sci. 17, 292-301 (2016).

21. Wethington, A. R. Family Physidae. In A supplement to the workbook accompanying the FMCS Freshwater Identification Workshop, University of Alabama, (Tuscaloosa, 2004).

22. Pip, E. \& Franck, J. P. C. Molecular phylogenetics of central Canadian Physidae (Pulmonata: Basommatophora). Can. J. Zool. 86, 10-16 (2008).

23. Gustafson, K. D., Kensinger, B. J., Bolek, M. G. \& Luttbeg, B. Distinct snail (Physa) morphotypes from different habitats converge in shell shape and size under common garden conditions. Evol. Ecol. Res. 16, 77-89 (2014).

24. Wethington, A. R. \& Lydeard, C. A molecular phylogeny of Physidae (Gastropoda: Basommatophora) based on mitochondrial DNA sequences. J. Mollus. Stud. 73, 241-257 (2007).

25. Bolton, M. S. \& Beaudoin, A. B. Recognizing macrofossils: A pictorial guide to some common seeds and shells from alluvial deposits in southern Alberta. In: After the flood: Investigations of impacts to archaeological resources from the 2013 flood in southern Alberta. Archaeological Survey of Alberta Occasional Paper 37, 156-168 (2017).

26. Gresens, S. E. 1995. Grazer diversity, competition and the response of the periphytic community. Oikos, 73, 336-34

27. Gari, E. N. \& Corigliano, M. C. Spatial and temporal variations of Cocconeis placentula var. euglypta (Ehrenb.) 1854 Grunow, 1884 in drift and periphyton. Braz. J. Biol. 67, 587-595 (2007).

28. Radea, C., Louvrou, I. \& Economou-Amilli, A. First record of the New Zealand mud snail Potamopyrgus antipodarum J.E. Gray, 1843 (Mollusca: Hydrobiidae) in Greece - Notes on its population structure and associated microalgae. Aquat. Invasions 3, 341-344 (2008).

29. Eagar, R. M. C. Shape and function of shell. Comparison of some living and fossil bivalve molluscs. Biol. Rev. Camb. Philos. Soc. 53, 169-210. PubMed PMID: WOS:A1978FC64800001 (1978)

30. Pfennig, D. W., Wund, M. A., Snell-Rood, E. C., Cruickshank, T., Schlichting, C. D. \& Moczek, A. P. Phenotypic plasticity's impacts on diversification and speciation. Trends Ecol. Evol. 25, 459-467. (2010).

31. Bousset, L., Pointier, J. P., David, P. \& Jarne, P. Neither variation loss, nor change in selfing rate is associated with the worldwide invasion of Physa acuta from its native North America. Biol. Invasions. 16, 1769-1783 (2014).

32. Wethington, A. R., Wise, J., \& Dillon Jr, R. T. Genetic and morphological characterization of the Physidae of South Carolina (Gastropoda: Pulmonata: Basommatophora), with description of a new 
species. Nautilus 123, 282 (2009).

33. Turner, A. M. \& Montgomery, S. L. Hydroperiod, predators and the distribution of physid snails across the freshwater habitat gradient. Freshw. Biol. 54, 1189-1201 (2009).

34. Saha, C., Pramanik, S., Chakraborty, J., Parveen, S. \& Aditya, G. Abundance and body size of the invasive snail Physa acuta occurring in Burdwan, West Bengal, India. J. Entomol. Zool. 4, 490-497 (2016).

35. Früh, D., Haase, P. \& Stoll, S. Temperature drives asymmetric competition between alien and indigenous freshwater snail species, Physa acuta and Physa fontinalis. Aquat. Sci. 79, 187-195 (2017).

36. Spyra, A. Acidic, neutral and alkaline forest ponds as a landscape element affecting the biodiversity of freshwater snails. Sci. Nat. 10 (2017).

37. Den Hartog, C. 1963 a. The distribution of the snail Aplexa hypnorum in Zuid-Beveland in relation to soil and salinity. Basteria 27, 8-17.

38. Den Hartog, C. 1963 b. The Aplexa hypnorum coenosis in Zuid-Beveland. Basteria 27, 49-63.

39. Byrne, A., Moorkens, E. A., Anderson, R., Killeen, I. J. \& Regan, E. C. Ireland Red List No. 2 - NonMarine Molluscs. National Parks and Wildlife Service, Department of the Environment, Heritage and Local Government, National Parks and Wildlife Service (Dublin, Ireland 2009).

40. Feliksiak, S. Physa acuta Draparnaud in den Fabrikteichen von Łódź und ihre allgemeine Verbreitung. Fragm. Faun. Mus. Zool. Pol. 4, 243-258 (1939).

41. Adam, W. Mollusques. I. Mollusques terrestres et dulcicoles. Institut royal des Sciences naturelles de Belgique. (Bruxelles 1960).

42. Backhuys, W. Land and fresh-water molluscs of the Azores. Backhuys \& Meesters, (Amsterdam 1975).

43. Abarca, V. C., Suarez, M. L. Lista faunistica y bibliografica de los moluscos (Gastropoda \& Bivalvia) de las aguas continentales de la Peninsula Iberica e islas Balares. Listas de la flora y fauna de las aguas continentales de la Península Ibérica. (1986).

44. Lisický, M.J. Mollusca Slovenska. VEDA. (Bratislava 1991).

45. Anderson, R. An annotated list of the land and freshwater Mollusca of Northern Ireland. Environment and Heritage Service Research \& Development Series (1997).

46. Turner H, Kuiper J.G.J., Thew N. et. al. Atlas der Molluskender Schweiz und Liechtensteins. Fauna Helv. 2:1-527 (1998).

47. Cossignani, T., Cossignani, V. Atlante delle conchiglie terrestri e dulciacquicole italiane. [Published for] Mostra mondiale malacologia by L'Informatore Piceno. (1995).

48. Beran, L. Which Physella (Mollusca: Gastropoda) lives in the Czech Republic? Acta Soc. Zool. Bohem. 68, 241-243 (2004).

49. Bank R. Towards a catalogue and bibliography of the freshwater Mollusca of Greece. Heldia 6:51-86 (2006). 
50. Yildirim, M.Z., Kebapc, U. , Gümüs, B.A., Koca, S.V. The basommatophoran pulmonate species (Mollusca: Gastropoda) of Turkey. Turk. J. Zool. 30, 445-458 (2006).

51. Son, M.O. Invasive species of Mollusca in fresh-and brackish waterbodies of the northern part of the Black Sea region. (in Russian) (Odessa UA, 2007).

52. Horsák, M., Juřičková, L., Beran, L., Čejka, T., Dvořák L. Komentovaný seznam měkkýšů zjištěných ve volné prírodě České a Slovenské republiky. [Annotated list of mollusc species recorded outdoors in the Czech and Slovak Republics]". Malac. Boh., Suppl. 1, 1-37 (2010).

53. Bódis, E., Borza, P., Potyó, I., et al. Invasive mollusc, crustacean, fish and reptile species along the Hungarian stretch of the river Danube and some connected waters. Acta Zool Hung 58, 29-45 (2012).

54. Laenko, T.M. The freshwater malacofauna of Byelorussia. Belaruskaya navuka. 128p. (Minsk, 2012).

55. Van Damme, D., Ghamizi, M., Seddon, M., Kristensen, T.K., Stensgaard, A.S., Budha, P.B., Dutta, J. Haitia acuta. The IUCN Red List of Threatened Species. http://dx.doi.org/10. 2305/IUCN.UK.2012.RLTS.T155538A732330.en. (2012).

56. Welter-Schultes, F. W. European non-marine molluscs, a guide for species identification, planet poster editions. Bestimmungsbuch für europäische Land-und Süsswassermollusken, (Göttingen, 2012).

57. Glöer, P., Die Süsswassergastropoden Nord- und Mitteleuropas, Bestimmungschlüssel, Lebenweise, Verbreitung, Die Tierwelt Deutschlands Begründet 1925 von Friedrich Dahl. 73. ConchBooks Publishing, (Hackenheim BRD, 2002).

58. Vinarski, M. V., Andreev, N. I., Andreeva, S. I., Kazantsev, I. .E., Karimov, A.V ., Lazutkina, E. A. Alien mollusk species in the aquatic ecosystems of Western Siberia: a review. Russ. J. Biol. Inv. 6, 137147 (2015).

59. CABI Data Mining - http://www.cabi.org. (2011).

60. http://www.faunaeur.org

61. http://www.animalbase.uni-goettingen.de

62. Ter Braak, C.J., Smilauer, P., 2002. CANOCO reference manual and CanoDraw for Windows user's guide: software for canonical community ordination (version 4.5). www. canoco. com.

\section{Figures}




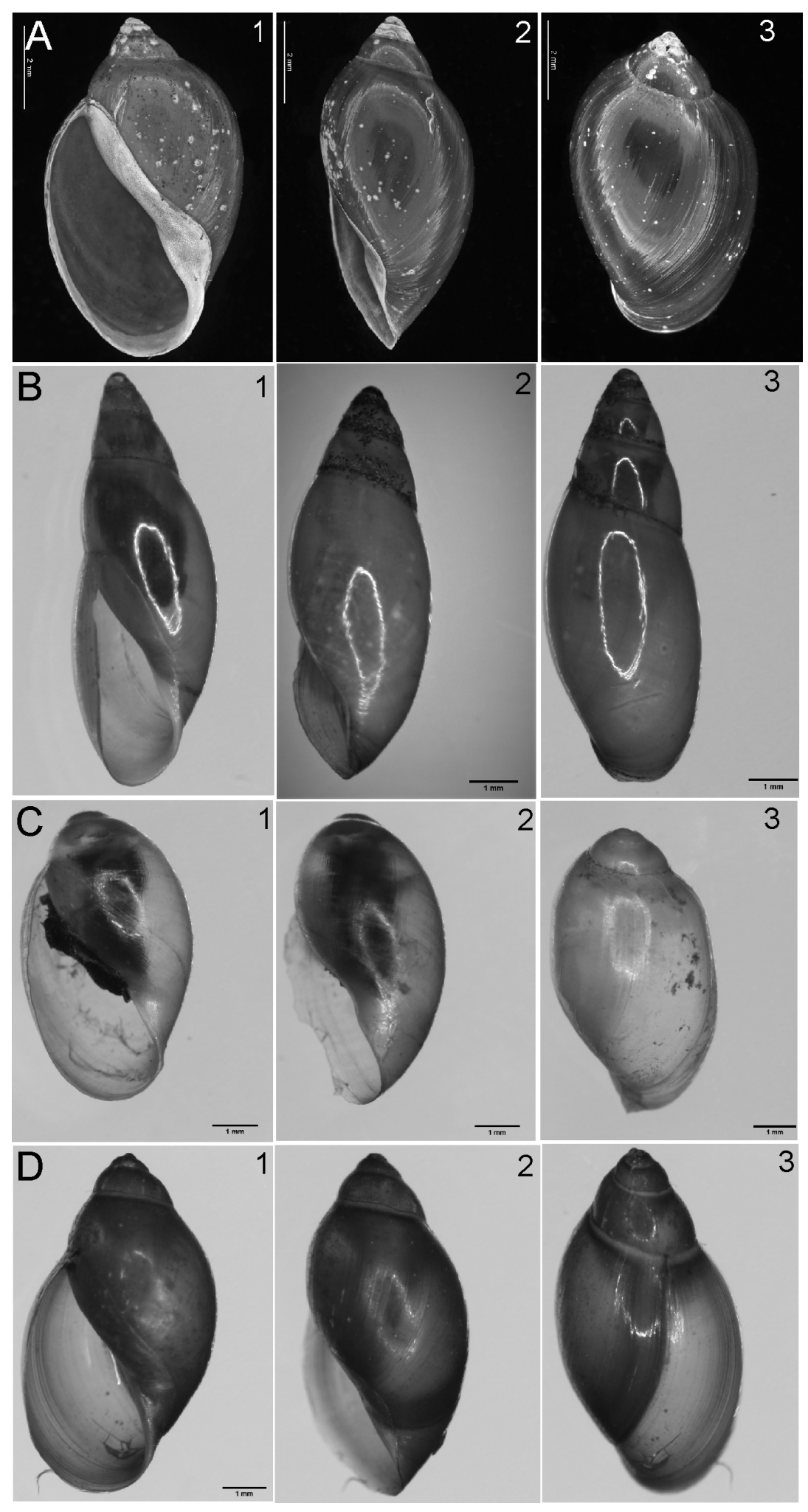

Figure 1

Physidae of western and central part of Europe - a general morphology of shells. A- Physa acuta (Phot. M. Kanturski), B- Aplexa hypnorum, C - Physa fontinalis, D - Physella gyrina; 1-front side of the shell, 2- shell from the side view, 3 - back side of the shell 


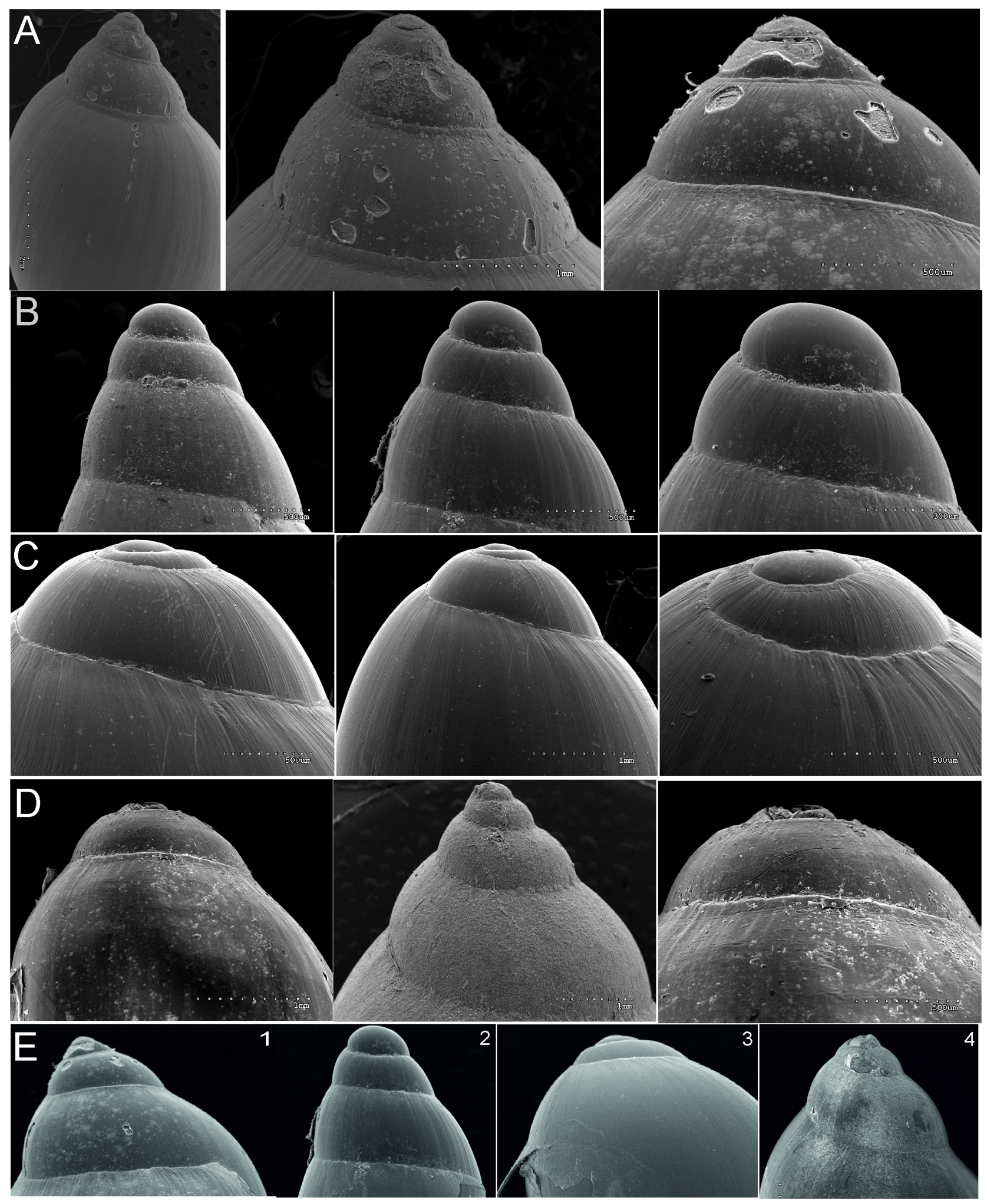

\section{Figure 2}

Scanning electron graphs of the shell apex of Physidae. Horizontally: A- P. acuta (subsidence ponds); BA. hypnorum (anthropogenic ponds, Poland); C - P. fontinalis (Nida River, Poland); D - P. gyrina (Ireland, The Argory- ditch and Sandy Bay L Neagh; Wales, Gwent Levels in pond in flood plain (I. Killen); E- Apex of the small (young) specimens- 1- P. acuta, 2- A. hyponorum, 3- P. fontinalis, 4- P. gyrina 


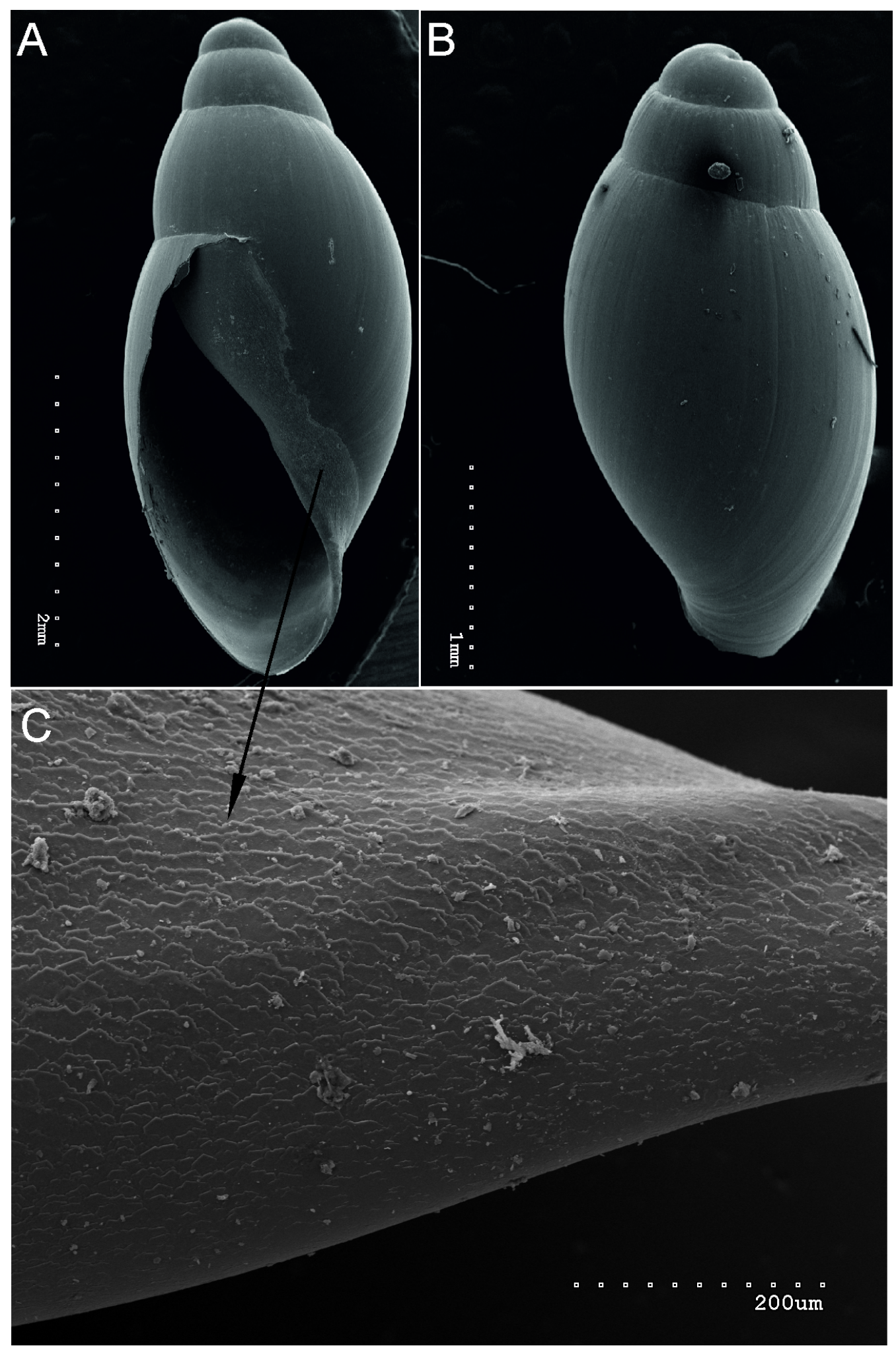

\section{Figure 3}

Scanning electron microscopy image of A. hypnorum shell. A, B- front (with visible lip) and back side of the shell, C- delicate structure on the lip 


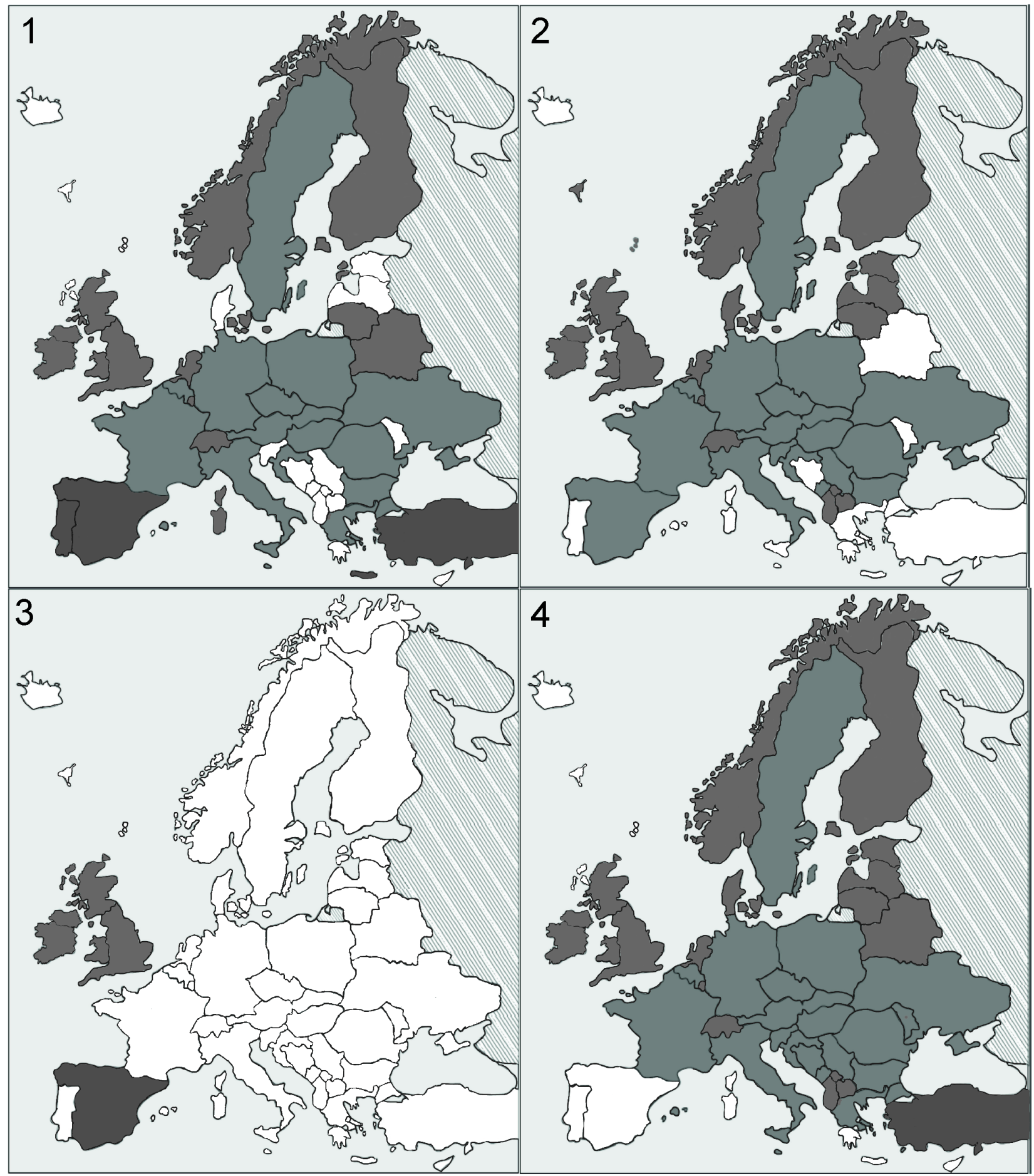

1

Area inhabited by species

scale: 1: 25000000

Figure 4

The range of occurrence of species from the family Physidae. 1- P. acuta, 2- A. hypnorum, 3- P. gyrina, 4 $P$. fontinalis $[8,10,13,16,18,20,40-61]$. Note: The designations employed and the presentation of the material on this map do not imply the expression of any opinion whatsoever on the part of Research Square concerning the legal status of any country, territory, city or area or of its authorities, or concerning the delimitation of its frontiers or boundaries. This map has been provided by the authors. 


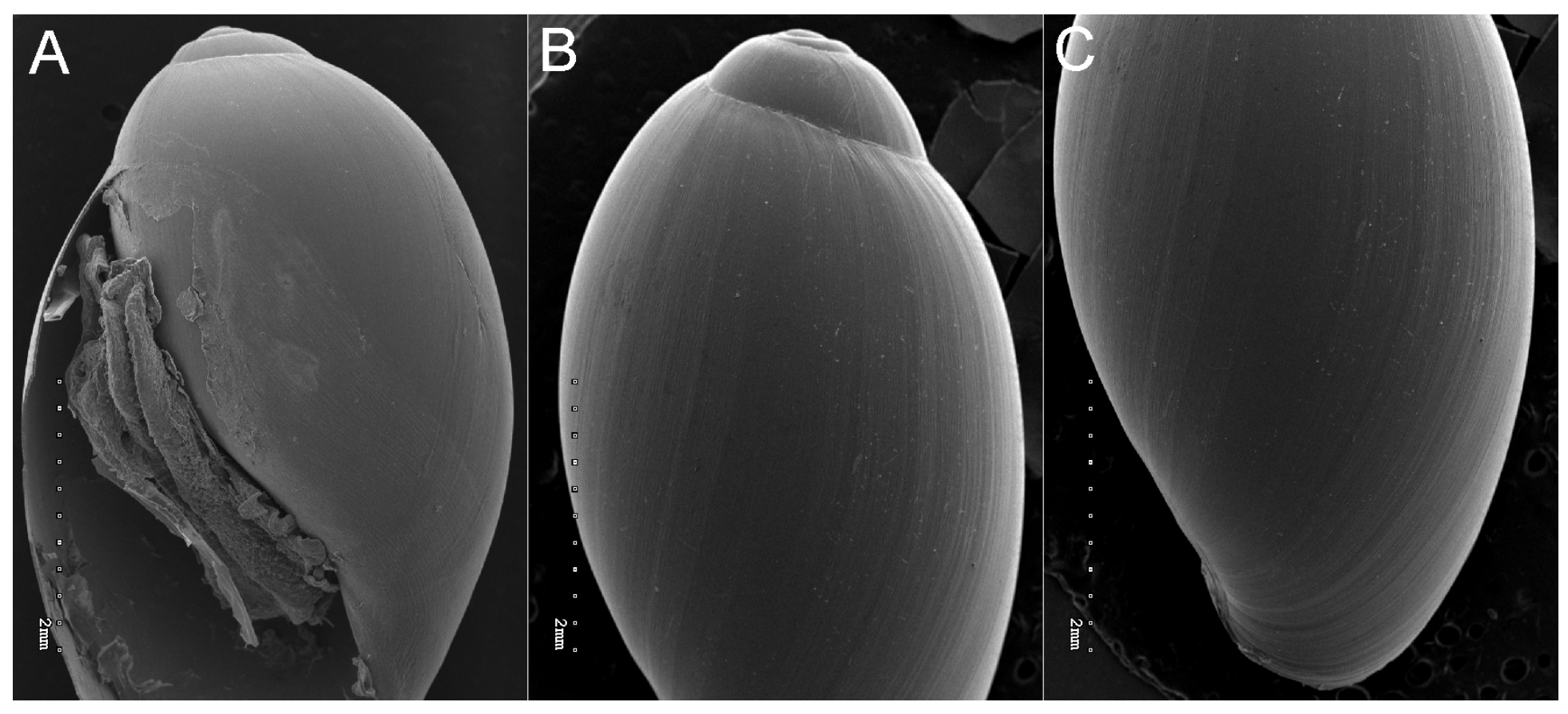

Figure 5

SEM micrograph of a P. fontinalis shell (A, B and C) 


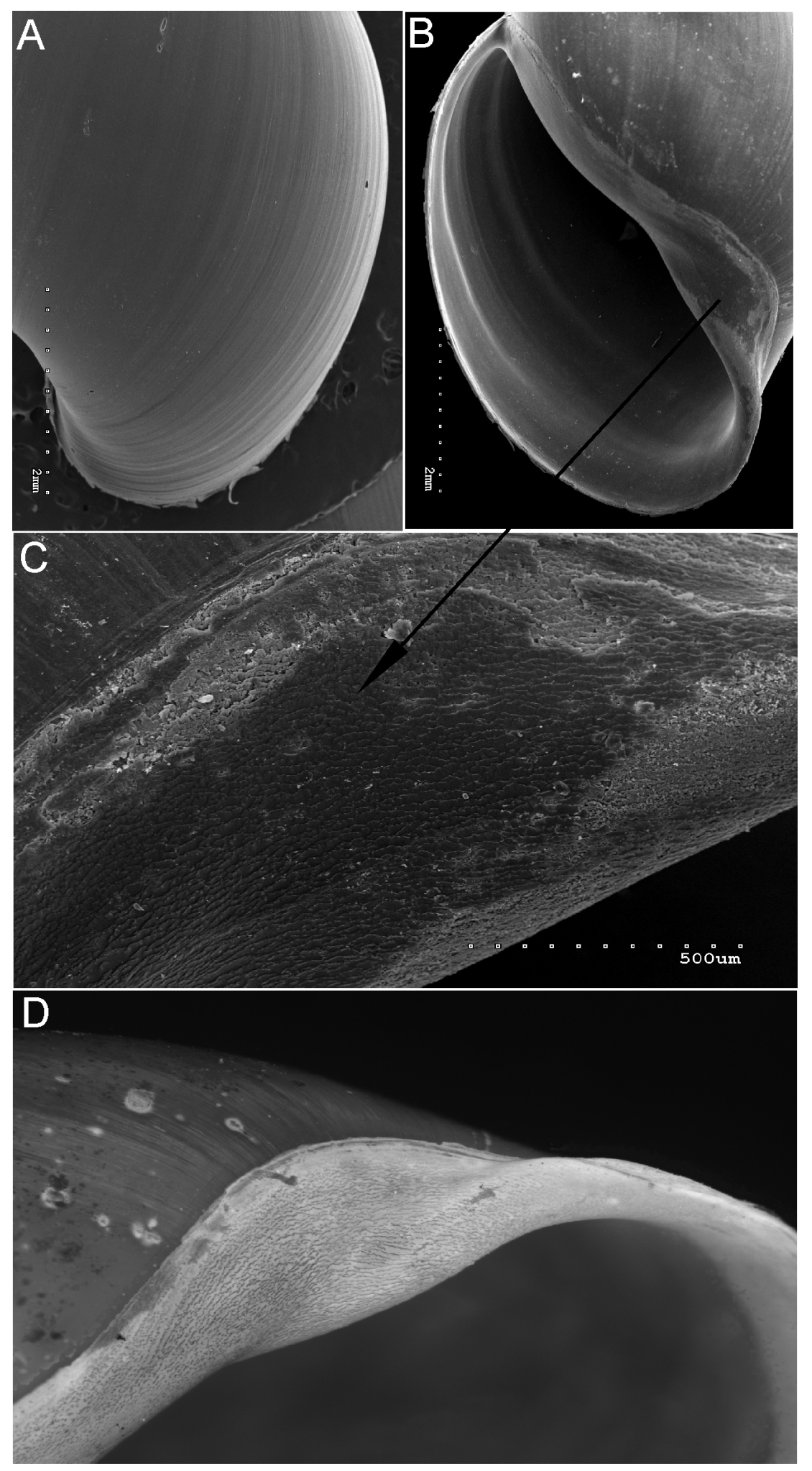

\section{Figure 6}

P. acuta shell features (SEM); in which the sutural belts are visible (A), the structure of a white lip (B) with characteristic striation (C) is indicated by an arrow, (D) a view of the lip visible under the stereoscopic microscope (Phot. M. Kanturski) 


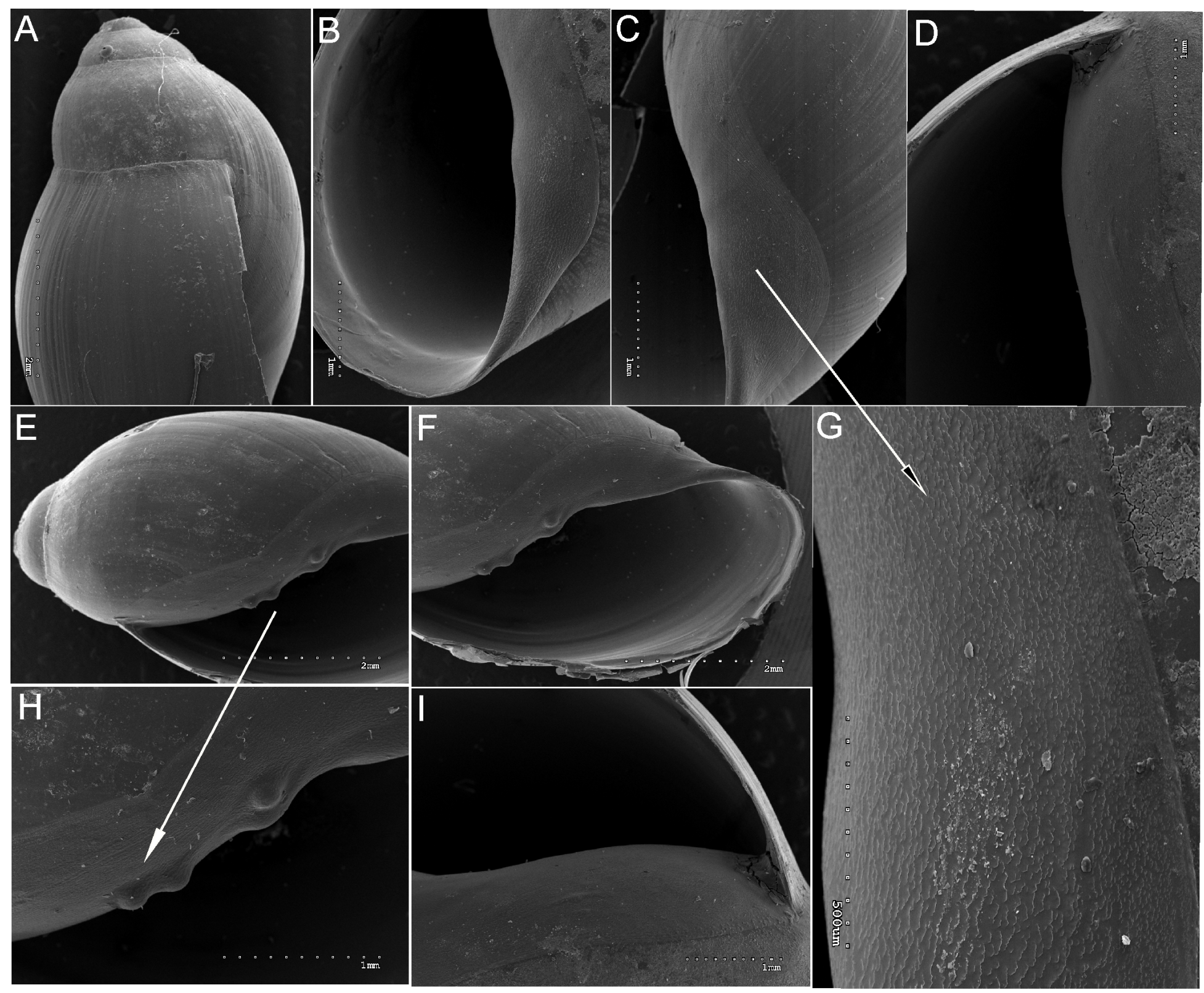

Figure 7

Characteristic features of P. Gyrina with special emphasis on the white lip. 


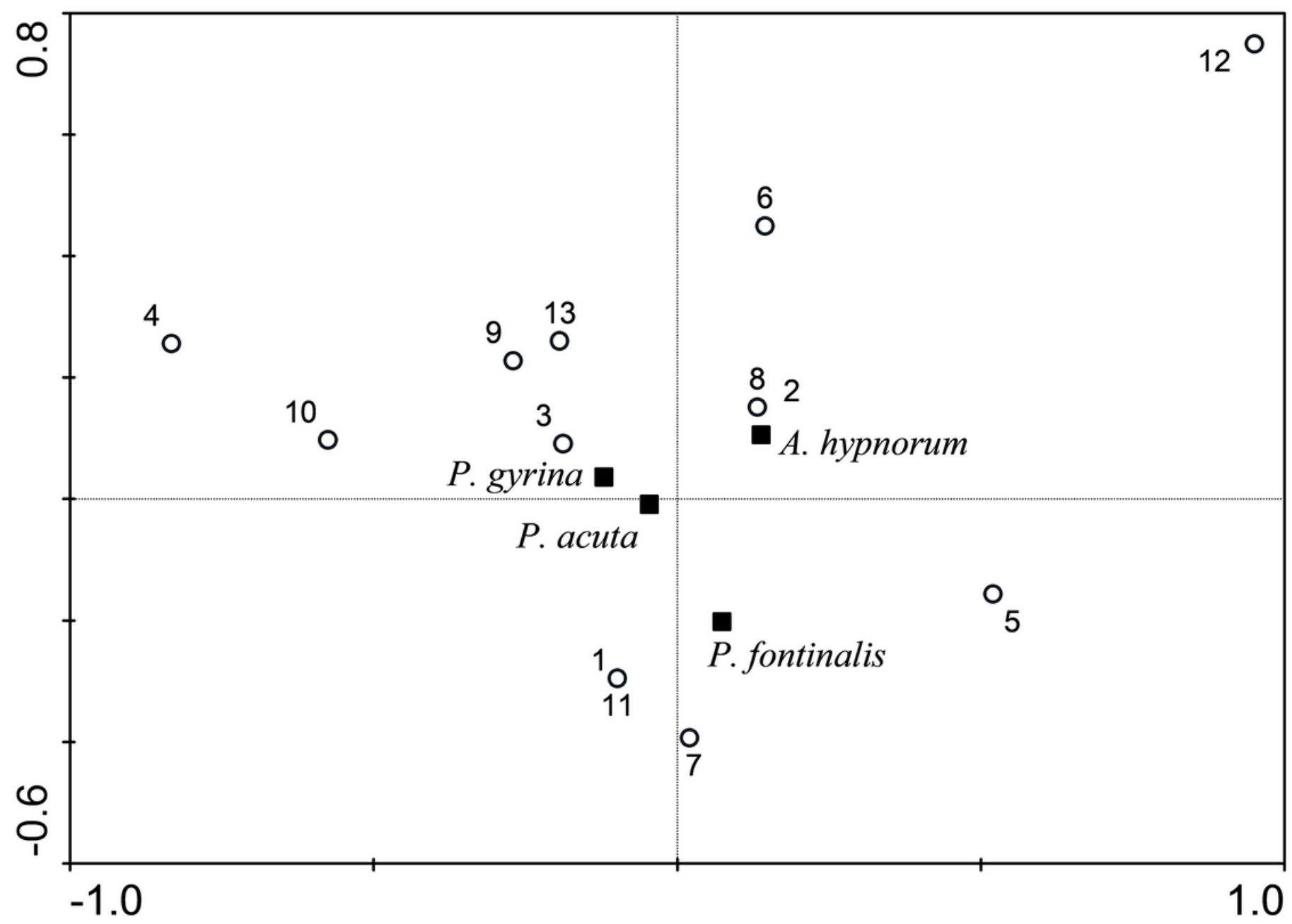

Figure 8

Correspondence Analysis (CA) diagram for the Physidae species; 1- Whorl convexity, 2- Spire, 3- Shell thickness, 4- Thickened appendages, 5- Shell shine, 6- Shell width and height ratio, 7- Aperture height, 8Shell height, 9- Lip, 10- Apex, 11-Shell width, 12- Aperture width, 13-Spire height

\section{Supplementary Files}

This is a list of supplementary files associated with this preprint. Click to download.

- Additionalfile1.pdf 